\title{
Artillery Through the Ages: AN etYMology
}

\section{Kevin Morton}

Artillery's 3,000-year history as one of the most brutally effective tools of war belies the poetic, mellifluous quality of its name. Most popularly recognized as " $[\mathrm{m}]$ achinery used for discharging projectiles in war," countless devices have passed in and out of history under the label artillery-from Gustavus Adolphus's three-pounder regimental cannons ${ }^{2}$ to Alexander the Great's ancient ballistas ${ }^{3}$ to the German army's legendary Paris Gun of World War I. Needless to say, artillery pieces have amassed quite a record of destruction over the millennia.

Nonetheless, the word itself still stands out as an unexpectedly beautiful one. Especially when compared to other war-related words such as gun, bomb, tank, trench, mine, and gas, the word artillery bears an elegance not entirely suited to its meaning.

Artillery has its origins in Anglo-Norman and Middle French, where it evolved from a verb meaning "to provide with weapons" and eventually came to be a collective term for various types of weaponry. Like so many other words, artillery made its way into the English language through Geoffrey Chaucer's late $14^{\text {th }}$ century classic, The Canterbury Tales. ${ }^{5}$ Chaucer debuts this word in the "Tale of Melibeus," the story of a wealthy young gentleman whose house is broken into and whose family is assaulted. The bulk of the tale consists of Melibeus consulting with his wife, Prudence, on how best to deal with the blackguards responsible, weighing his own kneejerk reaction to seek vengeance and the advice of his fellow citizens against her less hasty judgment. ${ }^{6}$ Melibeus announces early in the debate, "I shal warnestore myn hous wt toures swiche as han Castelles \& othere manere edifices \& armure \& Artelries by whiche thynges I may my persone \& myn hous..defenden." ${ }^{\text {.7 }}$ Read in Modern English, Melibeus proposes to fortify his home into a castle with towers and various armaments, so that no harm may come to himself or his family in the future. Prudence quickly convinces him to abandon this plan, primarily due to the expense of constructing and maintaining such fortifications, but also because it would make him seem prideful. ${ }^{8}$

In this context, artillery seems to follow its French roots: it refers to a general collection of armaments rather than the large-scale projectile-firing machines it has come to denote. Interestingly, Chaucer also uses it as a plural, count noun, whereas the modern usage is as a

\footnotetext{
${ }^{1}$ Artillery. (2008). In Oxford English Dictionary. Retrieved from http://www.oed.com/view/Entry/11226?redirectedFrom=artillery\&

${ }^{2}$ Brzezinski, R. (1993). Artillery. In The Army of Gustavus Adolphus (2): Cavalry. Retrieved from http://books.google.com/books?id=YylYMtCMz2UC\&pg=PA19\&lpg=PA19\&dq=The+Regimental+Cannon+Gustavus + Adolphus\&source=bl\&ots=Gu7DMfrQRz\&sig=fq5k8VRsYF_gjaGBiRGAXIwsfvQ\&hl=en\&sa=X\&ei=nN8wU8vNIMjn

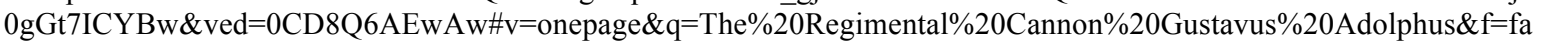
lse

${ }^{3}$ Ballista. (2014). In Encyclopedia Britannica. Retrieved from http://www.britannica.com/EBchecked/topic/50661/ballista

${ }^{4}$ Paris Gun. (2014). In Encyclopedia Britannica. Retrieved from http://www.britannica.com/EBchecked/topic/443856/Paris-Gun

${ }^{5}$ Artillery. (2008). In Oxford English Dictionary. Retrieved from http://www.oed.com/view/Entry/11226?redirectedFrom=artillery\&

${ }^{6}$ Chaucer, G. The Tale of Melibeus. In The Canterbury Tales. Retrieved from http://chaucer.classicauthors.net/CanterburyTales/CanterburyTales4.html

${ }^{7}$ Artillery. (2008). In Oxford English Dictionary. Retrieved from http://www.oed.com/view/Entry/11226?redirectedFrom=artillery\&

${ }^{8}$ Chaucer, G. The Tale of Melibeus. In The Canterbury Tales. Retrieved from http://chaucer.classicauthors.net/CanterburyTales/CanterburyTales4.html
} 
singular, collective noun; the OED lists few instances of this usage, however, and the word quickly became exclusively a collective noun after its first appearance in English.

Artillery acquired the connotation of ballistic machines and war engines several decades after its introduction, first applying to devices such as catapults, trebuchets, and bows that relied on weight displacement and recoil to fire projectiles. Unsurprisingly, it appeared mostly in the context of warfare, including John Lydgate's "Siege of Thebes" (an addendum and update to The Canterbury Tales, featuring many battles involving Oedipus's sons) and The Boke of Noblesse, an address to King Edward IV of England on the occasion of his late $15^{\text {th }}$ century invasion of France. ${ }^{9}$ Both texts refer to more antiquarian throwers of stone projectiles. It was not until the early $1500 \mathrm{~s}$, more than a century after its first use, that artillery began to describe explosive ordnance and gunpowder-based weaponry. The first known usage of the word to describe these more modern killing machines is found in Patrick Fraser Tytler's 1509 work The History of Scotland, wherein he mentions " $\mathrm{t}]$ hree hundred small artillery, under the names of myand, culverins, and double-dogs." "10 A few years later, in 1524, The Begynnynge and Foundacyon of the Holy Hospytall \& of the Ordre of the Knyghtes Hospytallers of Saynt Johan Baptyst of Jerusalem, a history of the Christian order of knights, makes numerous references to the artillery wielded by Turkish forces during the Crusaders' siege of Rhodes. ${ }^{11}$

Though cannons had been around for several hundred years prior to these publications, they did not come into their own as effective units of military hardware until the end of the Middle Ages. Technological advancements rendered knights, plate armor, and other more traditional types of weaponry obsolete around this time, which explains why the word artillery disappeared in reference to archery at the same time as the definition regarding explosive weapons came to prominence. The word merely followed the advancement of armaments, from slingshots to catapults to massive Turkish bombards and more modern cannons.

By extension, the word came to refer to the ammunition fired by such weapons as well, first documented in Sir Thomas Elyot's The Defence of Good Women. He used it figuratively, referring to the slights against women by poets as "artillery" and going on to defend women by claiming that no worthy philosopher "wrate any thynge in dysprayse of womankynde"12 (the first literal use in the sense of ammunition can be found in Arthur Golding's translation of Julius Caesar's Martiall Exploytes in Gallia ${ }^{13}$ ). A similarly metaphorical sense developed to mean armaments of the intellect - mental acuity and resources "deployed to achieve a desired end."14 Robert Dallington's 1592 translation of Francesco Colonna's Hypnerotomachia: The Strife of Loue in a Dreame mentions "the violent force of [Cupid's] artillerie,"15 and Abraham Cowley in

\footnotetext{
${ }^{9}$ Artillery. (2008). In Oxford English Dictionary. Retrieved from http://www.oed.com/view/Entry/11226?redirectedFrom=artillery\&

${ }^{10}$ Artillery. (2008). In Oxford English Dictionary. Retrieved from http://www.oed.com/view/Entry/11226?redirectedFrom=artillery\&

${ }^{11}$ Copland, R. and de Bourbon, J. (1524). The Begynnynge and Foundacyon of the Holy Hospytall \& the Ordre of the Knyghtes Hospytallers of Saynt Johan the Baptyst of Jerusalem. Retrieved from http://quod.lib.umich.edu/e/eebo/A04910.0001.001?rgn=main;view=fulltext

${ }^{12}$ Elyot, T. (1540). The Defence of Good Women. Retrieved from http://babel.hathitrust.org/cgi/pt?id=mdp.39015003346304;view=1 up;seq=1

${ }^{13}$ Caesar, Caius Julius. (1565). In A. Golding (Trans.), The Eyght Bookes of Caius Iulius Casar Conteyning His Martiall Exploytes in the Realme of Gallia. Retrieved from http://quod.lib.umich.edu/e/eebo/A17521.0001.001/1:13?rgn=div1;view=fulltext

${ }^{14}$ Artillery. (2008). In Oxford English Dictionary. Retrieved from http://www.oed.com/view/Entry/11226?redirectedFrom=artillery\&

${ }^{15}$ Colonna, F. (1592). In R. Dallington (Trans.), Hypnerotomachia: The Strife of Loue in a Dreame. Retrieved from http://www.gutenberg.org/files/18459/18459-h/18459-h.htm (Original work published 1499)
} 
his 1656 poem "The Chronicle" describes a particularly intelligent woman as "Arm'd with a resistless flame,/And th' artillery of her eye."16

By the $17^{\text {th }}$ century, the word's domain had extended from war machines themselves to the ammunition they fired, and even further to the military units responsible for their deployment. Sir James Balfour references in the third volume of his Historical Works a "Generall of the Artilizirie," an officer in command of such a force. ${ }^{17}$ A poetic substitution of "artillery" for "thunder and lightning" developed well after the other meanings, with the first use of the word in such a metaphorical fashion attributed to William Shakespeare in The Taming of the Shrew. ${ }^{18}$ Given the monstrous sound of a cannon's discharge, it is not difficult to see where the connection arose between artillery and thunder.

Modern language prizes the word as a title and not merely an object, likely due to its violent connotation, but perhaps also out of a subconscious appreciation for the form of the word itself. A quick Google search for "artillery" provides, to no surprise whatsoever, a Wikipedia entry before all other results; but, aside from several definitions of the word, the main results seem to use artillery as a proper noun. One is an "alternative contemporary" art magazine, most likely named Artillery for the sake of being ironic; other results include a graphic design company, a video game developer, an art gallery, and a record label-all bearing the name Artillery - not to mention several sites related to the US military. Not to be overlooked, of course, is the legendary Danish thrash metal band Artillery, whose seminal 1990 album "By Inheritance" set a new standard for technically complex metal. Several pages of results reveal that artillery is quite a popular name for various companies or other entities.

When it is used in reference to weaponry, it retains the meaning given to it in the $16^{\text {th }}$ century: "large-calibre firearms used both offensively and defensively in military operations." 19 In modern times, this is the only common definition of the word, though it may be found in many different places-board games (Axis \& Allies), television shows (" $\mathrm{M} * \mathrm{~A} * \mathrm{~S} * \mathrm{H}$ "), music (any Sabaton song)—employed in the same fashion. As missiles and other technologies render artillery obsolete, it seems that this definition might also be its last, though there are always endless opportunities for evolution, resurrection, and survival in idioms.

\footnotetext{
${ }^{16}$ Cowley, A. (1656). The Chronicle. In Poems. Retrieved from http://www.poemhunter.com/poem/the-chronicle-2/

${ }^{17}$ Balfour, J. (1657). The Historical Works of Sir James Balfour of Denmylne and Kinnaird, Knight and Baronet; Lord Lyon King at Arms to Charles the First, and Charles the Second: Volume III (p. 204). Retrieved from http://books.google.com/books?id=YN4GAAAAQAAJ\&pg=RA1-PA95\&lpg=RA1PA95\&dq=Balfour+Historical+Works\&source=bl\&ots=Wqn7_K4aG\&sig=1 ayCEd29RXboIHsVXcWpajIkwu8\&hl=en\&sa=X\&ei=uBo5U7LCDuTF0QHs54CYDw\&ved=0CDQQ6AEw $\mathrm{BDgK} \# \mathrm{v}=$ onepage $\& \mathrm{q}=$ Balfour $\% 20$ Historical $\% 20$ Works $\& \mathrm{f}=$ false

${ }^{18}$ Artillery. (2008). In Oxford English Dictionary. Retrieved from http://www.oed.com/view/Entry/11226?redirectedFrom=artillery\&

${ }^{19}$ Artillery. (2008). In Oxford English Dictionary. Retrieved from http://www.oed.com/view/Entry/11226?redirectedFrom=artillery\&
} 